\title{
HUBUNGAN ANTARA TINGKAT RELIGIUSITAS DENGAN KEMAMPUAN DALAM MENGATASI STRES (COPING STRESS)
}

\author{
Ira Darmawanti \\ Program Studi Psikologi Universitas Negeri Surabaya \\ e-mail: ira.darmawanti@gmail.com
}

\begin{abstract}
This study examined the relationship between religiosity and coping stress among participants who joined a religious community. The level of stress was controlled. Seventy nine participants whose age ranged from 21 to 28 involved in the study. Data were analysed using Pearson's Product Moment and resulted $r=0.6344$ and $p<0,001$ in the level of significance 5\%. The study found that higher level of religiosity was related with the better coping stress strategy, thus, it can be concluded that the higher the level of the religiosity among participants the more likely that they would be better in coping stress.
\end{abstract}

Keywords : religiosity, coping stress

\begin{abstract}
Abstrak: Penelitian ini bertujuan untuk mengetahui apakah ada korelasi yang positif antara tingkat religiusitas dengan coping stress dengan mengendalikan tingkat stres. Variabel yang dikaji dalam penelitian ini adalah variabel tingkat religiusitas sebagai variabel bebas, variabel coping stress sebagai variabel terikat. Populasi dalam penelitian ini adalah anggota kelompok pengajian di Surabaya berjumlah 95 orang dengan sampel sebanyak 79 orang. Teknik analisis yang digunakan adalah korelasi Product Moment dari Pearson. Berdasarkan hasil analisis data, untuk uji satu ekor dan taraf signifikansi $5 \%$ diperoleh $\mathrm{r}=0,6344$ dengan $\mathrm{p}<0,001$ yang berarti dengan mengendalikan tingkat stres, semakin tinggi tingkat religiusitas seseorang, semakin baik pula coping stress-nya.
\end{abstract}

Kata kunci: religiusitas, coping stress

Perubahan-perubahan sosial dapat membawa perubahan dalam cara berpikir dan pola kehidupan masyarakat, terutama pada masa sekarang ini ketika bangsa Indonesia dihadapkan pada masa-masa sulit akibat kondisi ekonomi dan politik yang tidak menentu. Dalam krisis yang berlangsung lama ini, banyak hal dapat menjadi sumber keresahan sosial. Krisis memang cenderung menggandakan akibat yang ditimbulkannya (multiplier effect). Kehadiran krisis secara obyektif dapat melahirkan krisis lain bersifat subyektif dalam tanggapan, reaksi, sikap, dan perasaan orang-orang yang terlibat (Surabaya Post, 1998).

Stres bukan fenomena baru dalam kehidupan manusia. Menurut Monat dan Lazarus (dalam Safaria, 2005) stres merupakan segala peristiwa atau kejadian yang berupa tuntutan-tuntutan lingkungan (eksternal) maupun tuntutan-tuntutan dari dalam diri individu (internal), bersifat fisiologis atau psikologis yang menuntut, membebani atau melebihi kapasitas sumber daya adaptif individu. Keadaan-keadaan yang menimbulkan stres ini selanjutnya mendorong individu untuk mengatasinya. Usaha tersebut disebut sebagai coping stress, yang merupakan usaha individu dalam mengatasi atau memanajemeni masalah-masalah yang menimbulkan stres. Dalam mengatasi permasalahan, usaha seseorang tidak hanya terpusat pada pemecahan masalah, tetapi juga pada pengurangan (usaha untuk mengurangi) perasaan-perasaan tertekan akibat permasalahan yang dihadapi.

Tentunya usaha dalam melakukan coping juga dipengaruhi beberapa hal, di antaranya (menurut Edward, 1990) adalah tingkat stres yang dialami individu. Individu 
yang mengalami tingkat stres yang rendah akan menggunakan strategi coping yang sama atau serupa dengan yang pernah dialami sebelumnya, namun individu yang mengalami stres yang lama atau kuat (memiliki tingkat stres tinggi) akan membentuk suatu strategistrategi yang baru. Stres yang meningkat akan memotivasi individu untuk menghasilkan serangkaian alternatif coping, dan individu yang mengalami tingkat stres tinggi ini pada umumnya akan mengalami hal-hal seperti kesedihan emosional, kebingungan, putus asa, marah, dan lain lain.

Salah satu penyebab individu mudah terombang-ambing dalam kebimbangan, keragu-raguan dan kehilangan makna hidup adalah dunia spiritual yang mulai ditinggalkan. Hal ini tentunya dapat memunculkan stres karena pada dasarnya agama (yang merupakan salah satu sumber spiritualitas) dapat memunculkan ketenangan dalam diri individu. Spiritualitas/religusitas merupakan pengalaman yang universal yang tidak hanya terdapat dalam kegiatan-kegiatan ritual keagamaan di tempat-tempat ibadah namun juga pada keseluruhan aspek kehidupan manusia (Safaria, 2005)

Ditambahkan pula oleh Mangunwijaya (1990), religiusitas merupakan aspek personal dari kehidupan yang beragama, mencakup totalitas rasa kedalaman pribadi dari individu itu sendiri. Religiusitas ini hanya dapat dihayati dari dalam, lebih menekankan kepasrahan diri dan rasa hormat pada Tuhan. Sekilas nampak hal ini sukar untuk diukur dan dinilai dari luar, namun religiusitas individu dapat diamati dari aspek-aspek kehidupan beragama di tengah-tengah pergaulan sosial.

Menurut Glock dan Stark (dalam Safaria, 2005), dimensi religiusitas meliputi lima hal sebagai berikut : 1) keyakinan (ideological); 2) praktek Agama atau peribadatan (ritualistic); 3) pengalaman/penghayatan (experiential/feeling); 4) pengetahuan (intelectual); dan 5) pengamalan (quensequential). Keyakinan ditunjukkan berkaitan dengan tingkatan sejauh mana seseorang berpegang teguh pada pandangan pandangan-pandangan teologis tertentu dan mengakui kebenaran doktrin-doktrin tersebut (terutama yang bersifat fundamental dan dogmatis) seperti keyakinan terhadap adanya Tuhan, hari akhir, surga dan neraka. Sementara praktek agama mencakup perilaku pemujaan, ketaatan, dan hal-hal yang dilakukan seseorang untuk menunjukkan komitmen terhadap agama yang dianutnya. Hal ini ditunjukkan oleh sejauh mana seseorang mengerjakan kewajiban ritual di dalam agamanya, misalnya mengerjakan shalat, berpuasa, berhaji, berdzikir, dan ibadah-ibadah lainnya.

Pengalaman atau penghayatan menunjuk pada seberapa jauh individu merasakan dan mengalami perasaan-perasaan dan pengalaman-pengalaman religius, misalnya selamat dari bahaya karena pertolongan Tuhan, merasakan ketenangan batin sehabis melaksanakan shalat dan berdoa. Keadaan perasaan mempunyai banyak fungsi dalam kehidupan beragama. Salah satunya bersifat motivasional. Tidak adanya perasaan yang sangat diinginkan (desired feelings) bisa jadi dirasakan sebagai suatu kesusahan, sehingga dapat memotivasi orang untuk mencari agama untuk memenuhi kesenjangan perasaan-perasaan tersebut, misalnya kurangnya arti yang dirasakan dalam kehidupan dapat menggerakkan seseorang ke arah agama, dengan harapan dalam agama arti yang dicari dapat ditemukan.

Pengetahuan menunjuk pada tingkatan sejauh mana seseorang mempunyai pengetahuan tentang ajaran agamanya dan aktivitas dalam menambah pengetahuan agamanya, misalnya kegiatan mengikuti kajian-kajian keagamaan, membaca buku-buku agama. Sementara pengamalan adalah dimensi yang mengukur sejauh mana perilaku seseorang dimotivasi oleh ajaran-ajaran agamanya atau sesuai dengan ajaran-ajaran agamanya, misalnya tidak mencuri, tidak bermain judi, atau tidak minum minuman yang memabukkan. 


\section{METODE}

Penelitian ini menggunakan studi korelasi untuk mengungkap keterkaitan antara tingkat religiusitas dan cara mengatasi stres (coping stress) dengan mengendalikan tingkat stres.

\section{Sampel}

Sampel dalam penelitian ini berjumlah 79 orang dari 95 orang anggota sebuah kelompok pengajian di Surabaya yang berusia 21-28 tahun, dengan tingkat pendidikan lulusan dari perguruan tinggi, dan memiliki tingkat stres yang tinggi. Pemilihan sampel penelitian menggunakan teknik simple random sampling di mana peneliti mengundi subjek penelitian yang terdaftar dalam populasi. Setiap subjek diberi nomor urut, kemudian semua nomor urut ditulis dalam kertas dan digulung dan selanjutnya dimasukkan ke tabung kecil lalu dikocok. Peneliti kemudian mengambil satu persatu gulungan kertas itu sampai sejumlah 79 orang.

\section{Teknik pengumpulan data}

Teknik pengumpulan data menggunakan kuesioner untuk variabel tingkat religiusitas, coping stress dan tingkat stres yang diungkap dengan modifikasi skala likert. Dalam hal ini dibuat pernyataan yang relevan dengan masalah yang diteliti yang dibedakan menjadi pernyataan favorable dan unfavorable. Setiap pernyataan dilengkapi dengan empat alternatif jawaban yaitu Sangat Sering (SS), Sering (S), Jarang (J) dan Tidak Pernah (TP). Jawaban yang ragu-ragu sengaja dihilangkan karena jawaban tengah akan banyak mengurangi informasi yang dapat dijaring dari responden.

\section{TeknikAnalisis Data}

Teknik analisis data yang digunakan adalah product moment dari Pearson, yang bertujuan untuk menguji hubungan antara tingkat religiusitas dan kemampuan mengatasi stres (coping stress)

\section{HASIL DAN PEMBAHASAN}

Hasil

Berdasarkan taraf signifikansi 5\%, diperolehlah koefisien korelasi sebesar $\mathrm{r}=$ 0,6344 dengan $p<0,001$. Skor ini memberi arti bahwa semakin tinggi tingkat religiusitas seseorang, semakin baik pula coping stressnya. Hasil ini menunjukkan bahwa ada hubungan positif antara religiusitas seseorang dengan coping stress-nya ketika tingkat stres dikendalikan.

\section{Pembahasan}

Coping stress merupakan proses yang terjadi dalam diri individu pada saat ia mengalami stres. Proses ini merupakan reaksi individu untuk dapat memberikan toleransi, menahan atau mengatasi dampak negatif dari stres. Fokus utama dalam mengelola stres menurut Doelhadi (1997) adalah untuk mengurangi atau meniadakan dampak negatif stres, dengan menangani dampak stres itu sendiri.

Tentunya, dalam melakukan coping seseorang tidak hanya sekedar menyelesaikan persoalan atau meredakan ketegangan yang timbul saja, namun juga ia perlu memperhatikan bagaimana meng-coping suatu permasalahan dengan adaptif dan efektif. Dengan kata lain coping yang dipergunakan adalah coping yang tidak merusak, baik bagi diri sendiri ataupun lingkungan.

Strategi coping yang digunakan individu dapat bermacam-macam dan lebih merupakan proses berangkai. Artinya individu akan terus mencoba beberapa strategi sampai dengan ditemukannya strategi yang sesuai. Coping berhasil bila individu dapat memasangkan dengan tepat antara beberapa alternatif coping dengan permasalahan yang ia hadapi. Selain itu, individu dituntut untuk dapat mengelola permasalahannya secara adaptif dan efektif sehingga tujuan dari coping itu sendiri dapat tercapai. 
Coping stress, menurut Edwards (1990), juga dipengaruhi oleh beberapa hal, di antaranya adalah waktu yang tersedia dan kepentingan individu. Adanya keterbatasan waktu tersebut menyebabkan individu harus mengambil keputusan yang cepat dan juga tepat, sehingga ketika waktu yang tersedia terbatas, individu cenderung menggunakan keputusan yang sederhana atau mudah (single minded decission rules) dan juga dengan adanya kepentingan yang meningkat, individu akan mengeluarkan banyak tenaga untuk menghasilkan alternatif coping yang sesuai. Selain itu, ketika individu pernah mengalami hal yang sama atau serupa di masa lampau, ia akan cenderung menggunakan strategi coping yang berhasil dan menghindari strategi coping yang pernah gagal.

Berkaitan dengan coping stres, dalam penelitian ini ditemukan adanya korelasi yang positif antara religiusitas seseorang dengan coping stress yang dilakukannya dengan mengendalikan tingkat stres atau dengan kata lain semakin tinggi tingkat religiusitas seseorang semakin tinggi pula coping stressnya. Hal ini sesuai dengan pernyataan Hawari (1996) bahwa religiusitas dapat mempertinggi kemampuan seseorang dalam mengatasi ketegangan-ketegangan (ability to cope) akibat permasalahan yang ia hadapi. Selain itu, individu yang religius atau memiliki religiusitas yang tinggi tentu memiliki pedoman dan daya tahan yang lebih baik dalam memanajemeni stres yang dihadapi. Artinya adalah bahwa individu yang memiliki tingkat religiusitas yang tinggi akan dapat mengambil nilai-nilai agama yang dianutnya untuk dipergunakan dalam memecahkan masalah atau dalam mengelola kondisi emosional yang tidak stabil akibat peristiwa-peristiwa yang menekan.

Berdasarkan penelitian Lindenthal dkk (dalam Safaria, 2005), diperoleh kesimpulan bahwa kelompok masyarakat yang religius jarang menderita stres dibanding dengan kelompok masyarakat yang kurang religius. Ditambahkan pula oleh Bergin dkk (dalam
Safaria, 2005), individu yang kontinu menjalankan komitmen agamanya ternyata memiliki stabilitas diri dan kebahagian hidup dibanding individu-individu yang tidak kontinu dalam menjalankan ajaran agamanya.

Menurut Rice, 1992; McMahon dan McMahon, 1986 (dalam Safaria, 2005), dimensi psikologis melalui kegiatan spiritual/religius (ritual dalam menjalankan praktek keagamaan) akan membuat individu dalam keadaan santai (relaksasi), tenang dan damai. Ditambahkan pula, ditinjau dari dimensi kesehatan, keadaan relaksasi dan membuat individu merasa tenang dan nyaman dapat mempengaruhi bagian otak manusia yang berkaitan dengan proses emosional, terutama pada bagian hipotalamus. Hipotalamus yang teraktivasi tersebut menghambat pengeluaran hormon corticotropinrealising factor (CRF) yang menyebabkan kelenjar anterior pituitary terhambat mengeluarkan adrenocortico-ticotrophic hormone $(\mathrm{ACTH})$, sehingga menghambat kelenjar adrenal untuk mengeluarkan cortisol, adrenalin dan noradrenalin. Hal ini menyebabkan hormon thyroxine yang dikeluarkan oleh kelenjar thyroidea dalam tubuh juga akan terhambat. Hormon thyroxine yang tinggi akan menyebabkan individu mudah merasa lelah, mudah cemas, mudah tegang dan susah tidur. Dengan kata lain keadaan relaksasi, tenang dan damai (mediatif) akan menimbulkan dampak psikis yang lebih tenang dan relaks.

Selain itu keadaan mediatif akan mempengaruhi dan menstimulasi susunan syaraf parasimpatis, yang akan mempengaruhi tekanan darah dan detak jantung, ketegangan otot-otot tubuh menurun sehingga menjadi rileks. Hal ini dapat berpengaruh pada keadaan psikologis yang menyebabkan individu memiliki perasaan santai, tenang, damai dan peningkatan kemampuan konsentrasi. Keadaan mediatif ini memunculkan gelompbang alpha pada otak yang menyebabkan keadaan individu tenang. Dengan keadaan tenang dan peningkatan 
konsentrasi, individu lebih mencari mencari alternatif / mengatasi (coping) stres yang dihadapi. Menurut Wtmer (dalam Safaria, 2005) menyatakan bahwa penggunaan praktek-praktek religius dan keyakinan spiritual sebagai tindakan coping memberikan dampak positif untunk mengatasi (coping) stres. Dengan kata lain salah satu jenis coping yang dapat dilakukan individu ketika dihadapkan pada masalah (stres) yang datang padanya adalah melalui pendekatan religius.

Namun, diperolehnya hasil yang berbeda antara penelitian yang dilakukan Rahayu (1997) di antaranya dapat disebabkan oleh adanya perbedaan dalam hal teknik analisis data (korelasi parsial jenjang tiga), variabel pengendali (tipe kepribadian), subyek penelitian, dan alat ukur.

Selanjutnya, mengenai perbedaan alat ukur coping stres, peneliti dalam penelitian ini menggunakan indikator: 1) membuat perencanaan; 2) menunggu kesempatan untuk bertindak; 3) mencari informasi guna membantu mengatasi masalah; 4) menerima kenyataan; 5) mengambil sisi positif dari suatu kejadian; 6) mencari ketenangan dalam ajaran agama; dan 7) pengendalian diri. Sedangkan pada alat ukur coping stres yang digunakan oleh Rahayu, indikatornya adalah: 1) denial; 2) penerimaan; 3) resignation; 4) pelarian diri dari masalah; 5) pengurangan beban masalah; 6) penyalahan diri, serta 7) pencarian arti.

Alasan tidak dipergunakannya alat ukur yang dimiliki Rahayu (1997) dalam penelitian ini adalah karena coping bukan hanya sekedar mengatasi suatu tekanan yang menimpa individu, tetapi coping juga merupakan suatu proses dari awal sampai akhir termasuk pemilihan strategi yang sesuai dengan karakteristik kejadian, bagaimana individu mengelola tekanan yang sedang dihadapi dengan strategi yang dipilih sampai dengan dapat tidaknya individu mengurangi atau meniadakan dampak stres itu sendiri.

Selain religiusitas, juga terdapat faktorfaktor lain yang turut mempengaruhi coping stress. Sarafino (1990) menyatakan bahwa individu yang memiliki tipe kepribadian A perilakunya cenderung untuk mengkritik dirinya sendiri dan dalam perjuangannya meraih tujuan ia tidak memiliki rasa senang dalam setiap usaha atau pencapaian yang telah ia dapatkan. Individu bertipe kepribadian A cenderung merasa dikejar-kejar waktu, mereka pada umumnya tidak sabar bila terjadi penundaan, memiliki komitmen terhadap jadwal yang telalu longgar, dan mereka mencoba melakukan lebih dari satu aktivitas dalam satu waktu; mereka cenderung lebih mudah untuk marah, dengan ekspresi kemarahan baik yang secara terbuka ataupun tertutup. Sebaliknya, individu yang bertipe kepribadian B lebih didasari oleh rendahnya tingkat kompetisi, kebutuhan akan tepatnya waktu dan kemarahan, mereka pada umumnya lebih easy going, dan lebih filosofis dalam menghadapi hidup.

Feldman (1993) menyatakan bahwa hardiness adalah karakteristik kepribadian yang dapat membedakan individu yang jatuh sakit dan tetap sehat saat mengalami stres, yang meliputi tiga komponen, yaitu: control, persepsi bahwa seseorang dapat menguasai kejadian dalam kehidupannya; challenge, yaitu anggapan individu bahwa perubahan yang terjadi merupakan suatu insentif/ kesempatan untuk maju daripada sebagai ancaman; commitment, yaitu kecondongan dalam diri seseorang bahwa aktivitas yang dilakukan itu penting dan mempunyai arti.

\section{SIMPULAN DAN SARAN}

Penelitian ini menghasilkan suatu kesimpulan bahwa ada korelasi yang positif antara tingkat religiusitas seseorang dengan coping stress-nya dengan mengendalikan tingkat stres. Dengan kata lain semakin tinggi tingkat religiusitas individu, maka semakin tinggi (baik) pula cara individu tersebut mengatasi stres (coping stress). Hasil yang diperoleh dalam penelitian ini hanya sebatas pada pembuktian ada tidaknya hubungan 
antara variabel $\mathrm{X}$ (tingkat religiusitas) dan variabel Y (coping stress), serta untuk mengetahui besar dan arah hubungan tersebut. Dengan demikian, penelitian ini bukanlah untuk menguji tentang hubungan sebabakibat dari dua variabel itu, sehingga tidak dapat disimpulkan secara sederhana tentang kausalitas hubungan dari dua variabel tersebut.

Saran yang dapat diajukan mempertimbangkan hasil penelitian ini di antaranya berkenaan dengan kepentingan ilmiah. Para peneliti lain yang tertarik dengan masalah ini disarankan untuk mengkaji kembali masalah ini dengan jangkauan yang lebih luas, sehingga hasilnya dapat digeneralisasikan secara lebih luas lagi dengan melibatkan faktor-faktor yang lain, seperti tipe kepribadian, jenis kelamin, dan sebagainya.

\section{DAFTAR PUSTAKA}

Doelhadi, E.M.A.S. (1997). Strategi dalam Pengendalian dan Pengelolaan Stres. Anima, Vol. XII, No. 48, Juli-September, $h$. 378-391.

Edwards, J.R. (1990). Causes, Coping and Consequences of Stress at Work: The Determinants and Consequences of Coping with Stress. New York: John Wiley and Sons.

Feldman, R.S. (1993). Understanding Psychology. Thrid Edition. New York: McGraw Hill.

Hawari, D. (1996). Zikir, Sarana Meraih Pahala dan Kemenangan Jiwa. Majalah Femina No. 5/XXIV 1-7 Februari, h. 43-45.
Mangunwijaya, Y.B. (1990). Sastra dan Religiusitas. Jakarta: Sinar Harapan.

Rahayu, H.P. (1997). Korelasi Tingkat Religiusitas dengan Perilaku Coping Stres. Jurnal Psikologika. No. 4/Tahun II, h. 6168.

Sarafino, E.P. (1990). Health Psychology: Biopsychoscial, Interaction. Second Edition. New York: John Willey and Sons, Inc.

Surabaya Post. (3 April 1998). Keresahan Masyarakat Hendaknya Bisa Dikurangi. hlm. 6 . 